\title{
REPLY TO COMMENTARIES
}

We thank the reviewers, Drs. K. Neve, B. L. Roth, D. R. Sibley, P. G. Strange, and D. F. Wong for their excellent and helpful comments. In considering these comments, the following questions arise:

\section{What Are the Neuroleptic Dissociation Constants for the Human Cloned Serotonin ${ }_{2 \mathrm{~A}}$ Receptors?}

Although all antipsychotic drugs occupy high levels of dopamine $\mathrm{D}_{2}$ receptors under clinical conditions (Seeman and Kapur submitted), it is unclear whether the additional blockade of serotonin $2 \mathrm{~A}\left(5-\mathrm{HT}_{2 \mathrm{~A}}\right)$ receptors may help to alleviate psychosis and whether such blockade may help to minimize antipsychotic-induced Parkinsonism.

As mentioned in the review, one of the main reasons for this uncertain role of $5-\mathrm{HT}_{2 \mathrm{~A}}$ receptors in antipsychotic action stems from the uncertain values for the dissociation constants of the various antipsychotic drugs at the $5-\mathrm{HT}_{2 \mathrm{~A}}$ receptors. As reviewed, this variation results partly from the fact that the apparent dissociation constant (or inhibition constant) of an antipsychotic drug depends on the radioligand used to label the receptor.

In addition, however, the dissociation constants for neuroleptics at the 5- $\mathrm{HT}_{2 \mathrm{~A}}$ receptor differ somewhat for the rat cerebral cortex compared and for the human cloned serotonin ${ }_{2 \mathrm{~A}}$ receptor.

As indicated by Drs. Neve, Roth, and Sibley, more data need to be provided for the dissociation constants at the serotonin $_{2 \mathrm{~A}}$ receptor. These data are now available, because the human cloned $5-\mathrm{HT}_{2 \mathrm{~A}}$ receptors have only recently become available.

Using these human cloned $5-\mathrm{HT}_{2 \mathrm{~A}}$ receptors, ${ }^{*}$ the new data in Table 2 give our recent results for the neuroleptic dissociation constants at this receptor. The first column in Table 2 (this article) shows the neuroleptic dissociation constant ( $K$ value) as determined using the method of Figure 2 (see review article), wherein the relation between the neuroleptic inhibition constant and the tissue:buffer partition was extrapolated down to the level of zero partition. This extrapolated radioligand-independent inhibition constant agrees with the dissociation constant of the neuroleptic at the $5-\mathrm{HT}_{2 \mathrm{~A}}$ receptor

${ }^{*}$ We thank Dr. R. K. Kamboj and Allelix Biopharmaceuticals, Inc. (Mississauga, Ontario) for generously providing these receptors. obtained by direct measurement using the radioactive form of the neuroleptic, such as $\left[{ }^{3} \mathrm{H}\right]$-clozapine.

\section{Are the Neuroleptic Dissociation Constants for the 5- $\mathrm{HT}_{2 \mathrm{~A}}$ Receptor Affected by Correcting the Radioligand Partition Values for Nonspecific Binding to the Filter?}

As correctly pointed out by Dr. K. Neve and by Dr. P. Strange, the tissue:buffer partition value of the radioligand (used in Figure 2 of the review or in Seeman and Van Tol 1995) represents the total amount of nonspecific binding of the radioligand to both the tissue and the filter. Hence, the question arises as to whether the neuroleptic dissociation constants for the 5- $\mathrm{HT}_{2 \mathrm{~A}}$ receptor are affected by correcting these radioligand partition values for nonspecific binding to the filter. This question also is examined in the following section for the dopamine $D_{2}$ and $D_{4}$ receptors.

The second column in Table 2 lists the radioligandindependent dissociation constants for neuroleptics at the human cloned 5- $\mathrm{HT}_{2 \mathrm{~A}}$ receptor, using partition values (for $\left[{ }^{3} \mathrm{H}\right]$-ketanserin and $\left[{ }^{3} \mathrm{H}\right]$-spiperone partitioning into rat cerebral cortex) from which the nonspecific binding to the filter had been subtracted. For example, the nonspecific binding of $1 \mathrm{nM}\left[{ }^{3} \mathrm{H}\right]$-ketanserin and $\left[{ }^{3} \mathrm{H}\right]$-spiperone to the filter was $39 \%$ and $22 \%$, respectively, of the nonspecific binding to rat cerebral cortex tissue in the presence of $1 \mu \mathrm{M}(+)$-butaclamol. After subtracting the filter-associated nonspecific binding from the nonspecific binding for the tissue plus filter, the results (second column in Table 2) show that the neuroleptic dissociation constants at the $5-\mathrm{HT}_{2 \mathrm{~A}}$ receptor were not affected by this revision of the partition values for the radioligands.

For purposes of comparison, the third column in Table 2 lists the $K$ values obtained experimentally from the neuroleptic/ $\left[{ }^{3} \mathrm{H}\right]$-ketanserin competition experiments, without any consideration for the partition of the radioligand. It may be seen that these neuroleptic dissociation constants versus $\left[{ }^{3} \mathrm{H}\right]$-ketanserin are only slightly higher than the radioligand-independent dissociation constants.

The data in Table 2, therefore, illustrate that the neuroleptic dissociation constants at the $5-\mathrm{HT}_{2 \mathrm{~A}}$ receptor were not significantly affected by the partition values of the radioligands. 
Table 1. Radioligand-independent Dissociation Constants

\begin{tabular}{lccccc}
\hline & D2 & D4 & 5-HT2A & D2:5-HT2A & D2:D4 \\
\hline Chlorpromazine & $0.66 \pm 0.05(12)$ & $1.15 \pm 0.04(9)$ & $3.5 \pm 0.06(9)$ & 0.19 & 0.58 \\
Clozapine & $44 \pm 8(27)$ & $1.6 \pm 0.4(96)$ & $11 \pm 3.5(9)$ & 4.00 & 28.00 \\
Fluphenazine & $0.32 \pm 0.03(7)$ & $50 \pm 10(11)$ & $80 \pm 19(6)$ & 0.004 & 0.0064 \\
Haloperidol & $0.35 \pm 0.05(18)$ & $0.84 \pm 0.05(54)$ & $25 \pm 8(5)$ & 0.014 & 0.42 \\
Isoclozapine & $6 \pm 0.06(15)$ & $5.8 \pm 0.08(19)$ & $1.5 \pm 0.05(9)$ & 4.2 & 1.03 \\
Loxapine & $5.2 \pm 0.03(15)$ & $7.8 \pm 1.5(25)$ & $10.2 \pm 1.2(5)$ & 0.51 & 0.67 \\
Melperone & $88 \pm 30(7)$ & $410 \pm 70(19)$ & $280 \pm 90(7)$ & 0.31 & 0.22 \\
Molindone & $6 \pm 3(9)$ & $2,400 \pm 800(11)$ & $5,800 \pm 1,300(6)$ & 0.001 & 0.0025 \\
Olanzapine & $3.7 \pm 0.6(12)$ & $2 \pm 0.4(22)$ & $5.8 \pm 0.7(14)$ & 0.64 & 1.85 \\
Perlapine & $60 \pm 10(8)$ & $30 \pm 10(10)$ & $30 \pm 12(6)$ & 2.00 & 2.00 \\
Raclopride & $0.64 \pm 0.12(13)$ & $620 \pm 100(40)$ & $5,400 \pm 1,700(4)$ & 0.00012 & 0.001 \\
Remoxipride & $30 \pm 25(8)$ & $2,800 \pm 400(9)$ & $3,100 \pm 400(4)$ & 0.01 & 0.011 \\
Risperidone & $0.3 \pm 0.1(19)$ & $0.25 \pm 0.1(17)$ & $0.14 \pm 0.1(5)$ & 2.14 & 1.2 \\
Seroquel & $78 \pm 28(13)$ & $3,000 \pm 300(14)$ & $2,500 \pm 600(5)$ & 0.03 & 0.026 \\
Sertindole & $0.95 \pm 0.4(22)$ & $0.85 \pm 0.2(18)$ & $0.3 \pm 0.06(8)$ & 3.10 & 1.12 \\
Thioridazine & $0.4 \pm 0.12(12)$ & $1.5 \pm 0.5(16)$ & $60 \pm 15(6)$ & 0.007 & 0.27 \\
Trifluperazine & $0.96 \pm 0.2(11)$ & $44 \pm 6(11)$ & $135 \pm 50(6)$ & 0.007 & 0.022 \\
\hline
\end{tabular}

In $\mathrm{nM} \pm \mathrm{SE}$ ( $n$ experiments in duplicate).

\section{Are the Neuroleptic Dissociation Constants for the $\mathrm{D}_{2}$ and $\mathrm{D}_{4}$ Receptors Affected by Correcting the Radioligand Partition Values for Nonspecific Binding to the Filter?}

There is very little change in the neuroleptic dissociation constants for the dopamine $D_{2}$ and $D_{4}$ receptors when the radioligand partition values were corrected for nonspecific binding to the filter.

In fact, the radioligand partition coefficient is composed of at least four components:

1. Nonspecific binding to the filter (negligible in the centrifugation method)

2. Nonspecific binding to the human tissue

3. Trapping within the filter (negligible in the centrifugation method)

4. Trapping within the buffer spaces enclosed by the membranes

With a centrifugation method to measure the partition values of the radioligands, the first and third components are zero, because there is no filter, and the fourth component tends to increase, depending on the centrifugal force used. Thus, it turns out that the partition values of the radioligand with the filtration and centrifugation methods were similar. For example, for human striatum tissue, the partition values for $\left[{ }^{3} \mathrm{H}\right]-$ nemonapride were 19.7 and 19.3 (filtration), and those for $\left[{ }^{3} \mathrm{H}\right]$-spiperone were 17 (centrifugation) and 13.3 (filtration). The units of partition are in (nmol radioligand/ $\mathrm{kg}$ of membrane) $/ \mathrm{nM}$ ) or dimensionless if it is assumed that the density of the original wet tissue is unity.
Drs. Neve and Strange properly request a more precise definition of the tissue:buffer partition coefficient. This has previously been done (Seeman 1972, 1980). For example, the precise membrane:buffer partition coefficients at $\mathrm{pH} 7.4$ for haloperidol and chlorpromazine are 200 and 1,700 $\mathrm{nmol}$ radioligand $/ \mathrm{kg}$ of membrane $/ \mathrm{nM}$ (Seeman et al. 1974; Seeman 1980). Although such precise values are interesting and may be useful for determining the molality or molarity of the drug within the 100 - $\AA$ biomembrane itself, the precise values, however, are not required to determine the radioligand-independent dissociation constant of a particular neuroleptic. That is, as long as the radioligand partition coefficients are measured relative to one another in a consistent manner, an extrapolation of the neuroleptic dissociation constants can be done in accordance with the simple procedure outlined in Figure 2 (see review).

To be consistent, therefore, all the radioligand partition values were measured by the filtration method. Using this method, we found that the values for the nonspecific binding of $1 \mathrm{nM}\left[{ }^{3} \mathrm{H}\right]$-raclopride, $1 \mathrm{nM}\left[{ }^{3} \mathrm{H}\right]-$ spiperone and $1 \mathrm{nM}\left[{ }^{3} \mathrm{H}\right]$-nemonapride averaged $39 \%$, $41 \%$, and $49 \%$, respectively, of the nonspecific binding of the human striatum tissue in the presence of $1 \mu \mathrm{M}$ (+)-butaclamol. After subtracting these amounts of filter-associated nonspecific binding from the tissue-plusfilter nonspecific binding, the final radioligand partition values were correspondingly lower. Despite this 39\% to $49 \%$ drop in the partition coefficients, as shown in Figure 6 (this article), the neuroleptic dissociation constants at the $D_{2}$ and $D_{4}$ receptors were almost identical to those in Table 1 (see review) wherein no allowance was 
made for nonspecific binding to the filter. This type of result, for example, is shown in Figure 6 for haloperidol.

\section{To What Extent Does the Depletion of the Radioligand (in a Filtration Assay) Affect the Dissociation Constant of the Competing Drug?}

Dr. Strange gives a brief, good review of the pitfalls in the time of equilibration and the depletion of radioligand in a filtration assay. He appropriately advises long equilibration times and large volumes, particularly when using a radioligand with a dissociation constant in the $\mathrm{pM}$ range. As previously stated (Seeman and van Tol 1995), we agree with Dr. Strange that depletion of the radioligand probably accounts for the apparent dependence of the neuroleptic dissociation constant on the partition of the radioligand. Nevertheless, we could not find evidence for such depletion of the radioligand when using very low concentrations of tissue, between $0.6 \mathrm{pM}$ and $10 \mathrm{pM}$ of $\mathrm{D}_{2}$ receptors (Seeman and van Tol 1995). Moreover, extensive corrections for radioligand depletion reduced but did not eliminate the apparent dependence of the neuroleptic dissociation constant on the partition coefficient (Seeman and van Tol 1995). It is clear, therefore, that the apparent dependence of the neuroleptic dissociation constant on the partition arises from an artifact in both the filtration assay and the centrifugation assay.

However, regardless of how this artifact arises (and we essentially agree with the detailed considerations by Dr. Strange), the extrapolation method in Figure 2 (see

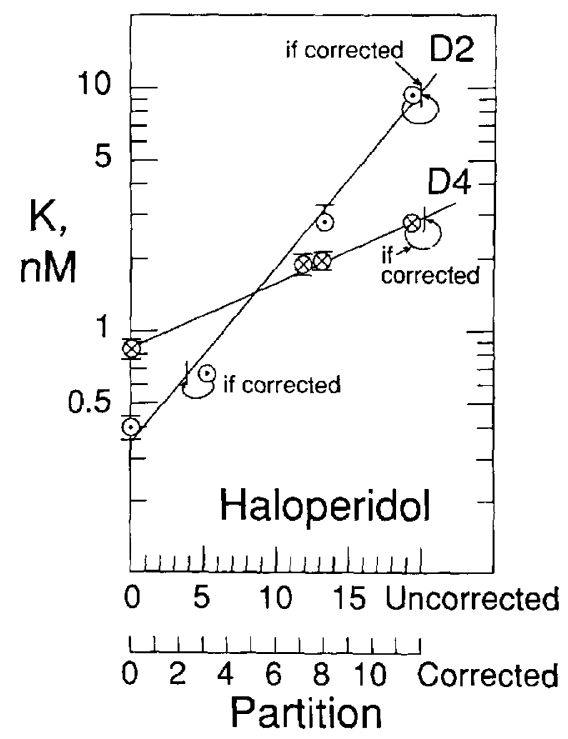

Figure 6. Partition of each radioligand corrected for the filter-associated nonspecific binding in the presence of $1 \mu \mathrm{M}$ (+)-butaclamol. Although this correction lowered the partition values by $39-49 \%$, the radioligand-independent dissociation constant of the neuroleptic $(\mathrm{K})$ was not affected. Further details as in Figure 2A. review) results in neuroleptic dissociation constants that match those measured directly with $\left[{ }^{3} \mathrm{H}\right]$-neuroleptic radioligands. Such a match has now been obtained for at least six $\left[{ }^{3} \mathrm{H}\right]$-neuroleptic radioligands: $\left[{ }^{3} \mathrm{H}\right]$-clozapine, $\left[{ }^{3} \mathrm{H}\right]$-haloperidol, $\left[{ }^{3} \mathrm{H}\right]$-olanzapine, $\left[{ }^{3} \mathrm{H}\right]$-chlorpromazine, $\left[{ }^{3} \mathrm{H}\right]$-raclopride, and $\left[{ }^{3} \mathrm{H}\right]$-sertindole, indicating that this match is more than just a coincidence, as stated by Dr. Strange.

\section{What Is the Synaptic Concentration of Dopamine in the Human Striatum?}

Drs. Neve and Strange provide a very good summary of the literature on this question and appropriately note that the dopamine concentration in the synapse may range from 6 to $600 \mathrm{nM}$, depending on the precise time point chosen during neurotransmission.

A main point in our review, however, is to indicate that the clinical efficacy or clinical occupancy of dopamine receptors by a neuroleptic depend on the local synaptic concentration of dopamine. This can be modeled in vitro. For example, although we have found that the clozapine dissociation constant at the human cloned dopamine $\mathrm{D}_{4}$ receptor is $1.6 \mathrm{nM}$ (see Table 1 in the review), in the absence of any dopamine, this clozapine dissociation constant rises to $10 \mathrm{nM}$ when competing against $4 \mathrm{nM}\left[{ }^{3} \mathrm{H}\right]$-dopamine and rises further to approximately $100 \mathrm{nM}$ when competing against $10 \mathrm{nM}$ $\left[{ }^{3} \mathrm{H}\right]$-dopamine (unpublished data). As reviewed, the concentration of clozapine in the spinal fluid under clinically therapeutic conditions is of the order of 20 to $40 \mathrm{nM}$. This suggests that the steady-state functional level of endogenous synaptic dopamine in the patients may be of the order of 6 to $8 \mathrm{nM}$, in approximate agreement with the value for the dissociation constant of dopamine at the high-affinity state of the dopamine $D_{2}$ and $\mathrm{D}_{4}$ receptors.

Dr. Wong appropriately mentions some of the literature indicating that the synaptic concentration of dopamine is controlled by serotonin. Indeed, there is an extensive literature on this, as mentioned in the review. What is not known, however, is whether the serotonin control of dopamine release is of sufficient influence to play a role in schizophrenia or in the treatment of schizophrenia (see later discussion).

Drs. Wong and Strange mention the important matter of the different percentage occupancies of $D_{2}$ receptors by clozapine in human subjects. Here, too, the occupancy by clozapine depends on the partition coefficient of the $\left[{ }^{11} \mathrm{C}\right]$-radioligand chosen. For example, Dr. Wong notes that $450 \mathrm{mg}$ / day of clozapine occupies $22 \%$ of the $\mathrm{D}_{2}$ receptors, when measured with $\left[{ }^{11} \mathrm{C}\right]-$ methylspiperone (Conley et al. 1996). Moreover, when the $\mathrm{D}_{2}$ receptors are measured with $\left[{ }^{11} \mathrm{C}\right]$-raclopride, such doses of clozapine occupy a higher level $(50 \%)$ of 
the $D_{2}$ receptors (Nordström et al. 1996). This is more fully discussed in a subsequent manuscript (Seeman and Kapur, submitted for publication), illustrating that these apparently different percentages of $D_{2}$ receptors occupied by clozapine can be fully resolved if one takes into account that the low partition coefficient of raclopride permits $\left[{ }^{11} \mathrm{C}\right]$ raclopride to be more readily occupied by clozapine than by $\left[{ }^{11} \mathrm{C}\right]$-methylspiperone, which has a high partition identical to that for spiperone.

\section{Using These New Dissociation Constants for Neuroleptics at the 5- $\mathrm{HT}_{2 \mathrm{~A}}$ Receptors, How Do These Values Relate to the Neuroleptic-Induced Catalepsy Doses?}

Using the new data for the human cloned $5-\mathrm{HT}_{2 \mathrm{~A}}$ receptor (Table 2 in this article), the relation between the neuroleptic doses (for catalepsy) and the neuroleptic selectivity for the $5-\mathrm{HT}_{2 \mathrm{~A}}$ receptor (relative to $\mathrm{D}_{2}$ ) is shown in Figure 7 (this article). The correlation coefficient was 0.48 , which was not statistically significant at the .05 level. The correlation omitted thioridazine because of its strong anticholinergic potency.

\section{Using the Slightly Modified Dissociation Constants for Neuroleptics at the Dopamine $D_{2}$ and $\mathrm{D}_{4}$ Receptors, How Do These Values Relate to the Neuroleptic-Induced Catalepsy Doses?}

Because the neuroleptic dissociation constants at the dopamine $D_{2}$ and $D_{4}$ receptors were hardly affected by correcting the radioligand partition values for the filterassociated nonspecific binding, the relation in Figure 5 was virtually not affected, as illustrated in Figure 7 (bottom). The correlation coefficient was 0.77 between the neuroleptic doses (for catalepsy) and the neuroleptic selectivity for the $D_{4}$ receptor (relative to $D_{2}$ ) (Figure 7 , bottom); this value was statistically significant at the $p<.02$ level. Here, too, as in Figure 7 (top), the correlation omitted thioridazine because of its strong anticholinergic potency.

Drs. Roth and Sibley state that the olanzapine preference of $D_{4}$ over $D_{2}$ by twofold and the clozapine preference of $\mathrm{D}_{4}$ over $\mathrm{D}_{2}$ by 28 -fold do not indicate selectivity but rather just a "preference." Perhaps "preference" may be a better word, but it is useful to remind ourselves that the dopamine $D_{2}$ receptor "prefers" dopamine only three-fold more than (-)-epinephrine (Burt et al. 1976). In other words, in the same way as a receptor is defined by the rank order or relative selectivity of endogenous agonists, so is a receptor antagonist defined by the relative rank order of antagonist action at various receptors. Hence, clozapine is selective, but not specific, for the dopamine $\mathrm{D}_{4}$ receptor.
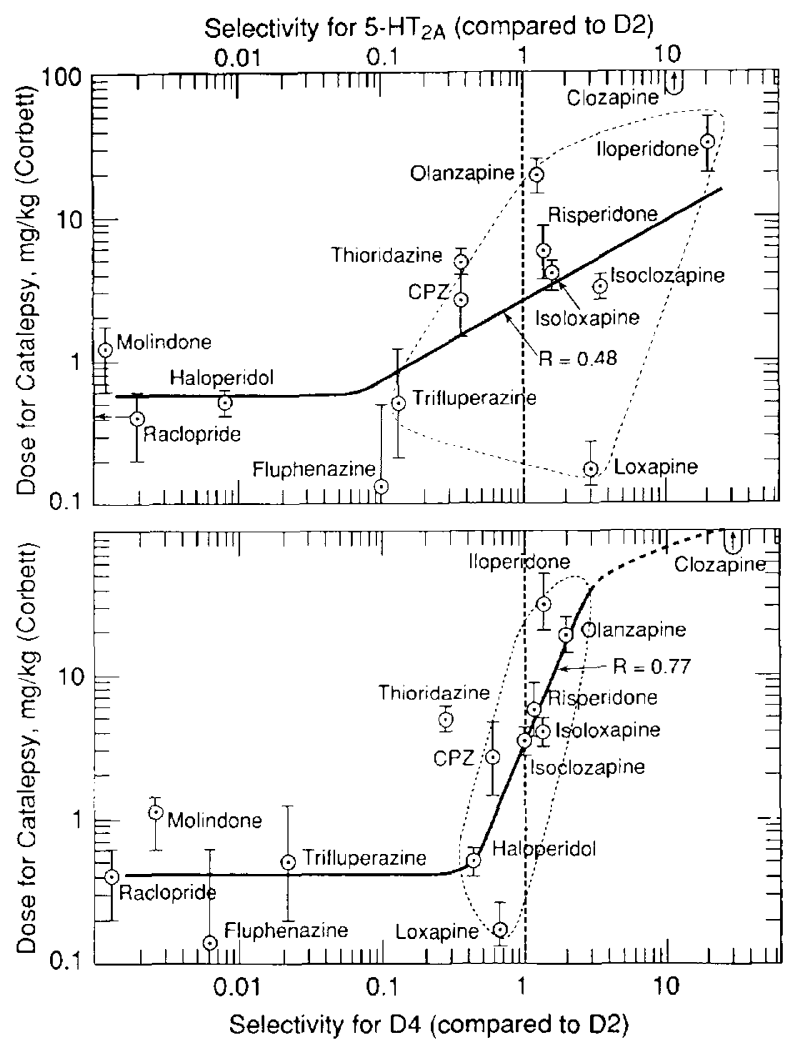

Figure 7. Top, neuroleptic doses for eliciting catalepsy (in $50 \%$ of the rats) versus the ratio of the neuroleptic radioligand-independent dissociation constants for the cloned dopamine $\mathrm{D}_{2}$ receptor and the human cloned serotonin $\mathrm{A}_{2}$ receptors (ratios derived from Tables 1 and 2). Bottom, neuroleptic doses (for catalepsy) versus the ratio of the neuroleptic radioligand-independent dissociation constants for the dopamine $\mathrm{D}_{2}$ and $\mathrm{D}_{4}$ receptors (ratios derived from Table 1 ). Thus the horizontal axis indicates the neuroleptic selectivity for the dopamine $D_{4}$ receptor relative to that for the dopamine $\mathrm{D}_{2}$ receptor. As in Figure 5, neuroleptics that had low affinity for the dopamine $\mathrm{D}_{2}$ receptors [remoxipride, perlapine, seroquel, and melperone (i.e., that have radioligandindependent dissociation constants exceeding $30 \mathrm{nM}$ )] were omitted in both correlations (top and bottom), based on the concept that these loosely bound neuroleptics are atypical because they are readily displaced by endogenous dopamine. The inclusion of these four neuroleptics with very low affinity for the dopamine $D_{2}$ receptor would vitiate the correlations. The correlation coefficient is given for the drugs encircled by a "balloon," omitting thioridazine because of its uniquely potent anticholinergic and anticataleptic action. The correlation coefficient of 0.77 (bottom) was statistically significant at the $p<.02$ level.

\section{Are Atypical Neuroleptics Selective in Stimulating the 5- $\mathrm{HT}_{1 \mathrm{~A}}$ Receptor?}

As summarized in the review, the $5-\mathrm{HT}_{1 \mathrm{~A}}$ receptor agonist 8-hydroxy-dipropylaminotetralin alleviates antipsychotic-induced catalepsy. Because clozapine also is a partial agonist at the human cloned $5-\mathrm{HT}_{1 \mathrm{~A}}$ receptor 
(Newman-Tancredi et al. 1996), we recently tested other atypical neuroleptics on the human cloned $5-\mathrm{HT}_{1 \mathrm{~A}}$ receptor using the method of Newman-Tancredi et al. (1996). We found no relation between the clinical propensity of the various neuroleptics to elicit Parkinsonism and their agonist potencies on the human cloned 5- $\mathrm{HT}_{1 \mathrm{~A}}$ receptor. Risperidone at $100 \mathrm{nM}$, for example, was 100 times more potent than clozapine or olanzapine in stimulating the $5-\mathrm{HT}_{1 \mathrm{~A}}$ receptor to incorporate $\left.{ }^{35} \mathrm{~S}\right]-\mathrm{GTP}-\gamma-\mathrm{S}$. In addition, isoclozapine and clozapine were equally effective in stimulating the serotonin $1 \mathrm{~A}$ receptor. Because the in vitro potencies of these latter four neuroleptics bear no relation to their clinical propensities to elicit Parkinsonism, it is unlikely that the $5-\mathrm{HT}_{1 \mathrm{~A}}$ receptor is involved in the action of atypical neuroleptics.

\section{Are Atypical Neuroleptics Selective for the $5-\mathrm{HT}_{6}$ Receptor?}

A good point made by Drs. Roth and Sibley is that clozapine and other atypical neuroleptics also have high affinities for the $5-\mathrm{HT}_{2 \mathrm{C}}, 5-\mathrm{HT}_{6}$, and $5-\mathrm{HT}_{7}$ receptors (Roth et al. 1994). For example, in comparison to the clozapine dissociation constants of $1.6 \mathrm{nM}$ at the $\mathrm{D}_{4}$ receptor and of $44 \mathrm{nM}$ at the $\mathrm{D}_{2}$ receptor, clozapine has a dissociation constant of $4 \mathrm{nM}$ at the $5-\mathrm{HT}_{6}$ receptor and $6.3 \mathrm{nM}$ at the $5-\mathrm{HT}_{7}$ receptor. Further examples are sertindole with dissociation constants of $0.95 \mathrm{nM}$ at $\mathrm{D}_{2}, 0.85 \mathrm{nM}$ at $\mathrm{D}_{4}$ (Table 1 of the review), and $0.3 \mathrm{nM}$ at $5-\mathrm{HT}_{2 \mathrm{~A}}$ (Table 2 in this article) and olanzapine with dissociation constants of $3.7 \mathrm{nM}$ at $\mathrm{D}_{2}, 2 \mathrm{nM}$ at $\mathrm{D}_{4}$ (Table 1), $2.3 \mathrm{nM}$ at $5-\mathrm{HT}_{2 \mathrm{~A}}$ (Table 2), $2.5 \mathrm{nM}$ at $5-\mathrm{HT}_{6}$, and $104 \mathrm{nM}$ at $5-\mathrm{HT}_{7}$ (Roth et al. 1994).

Therefore, because of such relatively high affinities for serotonin receptors for some atypical neuroleptics, Drs. Roth and Sibley ask "Why then all the fuss about the dopamine $\mathrm{D}_{4}$ receptor?" A more compelling question is: "Why has there been such a fuss about serotonin receptors in schizophrenia these past 10 years when there is little or no compelling evidence and no clinical correlate indicating that serotonin receptors have any clinical role in schizophrenia, its treatment, or any role in alleviating neuroleptic-induced Parkinsonism?"

These questions are precisely why this review was prepared. Which receptor, if any, needs to be blocked to balance the Parkinsonism elicited by $\mathrm{D}_{2}$ blockade? Could it be $\mathrm{D}_{4}, 5-\mathrm{HT}_{1}, 5-\mathrm{HT}_{2 \mathrm{~A}}, 5-\mathrm{HT}_{6}$, or $5-\mathrm{HT}_{7}$, or could it be none of these? This is precisely the reason for obtaining

Table 2. Dissociation Constants (nM) of Antipsychotic Drugs at the Human Cloned $5-\mathrm{HT}_{2 \mathrm{~A}}$ Receptor

\begin{tabular}{|c|c|c|c|}
\hline & \multicolumn{2}{|c|}{ Ligand-Independent $K$ Values } & \multirow[b]{2}{*}{$\begin{array}{c}\text { K Using }\left[{ }^{3} \mathbf{H}\right]- \\
\text { ketanserin }\end{array}$} \\
\hline & Not Corrected ${ }^{n}$ & $\begin{array}{c}\text { Filter- } \\
\text { Corrected }^{b}\end{array}$ & \\
\hline Chlorpromazine & $1.8 \pm 0.2$ & 1.8 & 2 \\
\hline Clozapine & $3.5 \pm 0.4$ & 3.5 & 3.8 \\
\hline$\left[{ }^{3} \mathrm{H}\right]$-clozapine & 3.2 & & \\
\hline Fluphenazine & $3.2 \pm 0.5$ & 3.1 & 3.8 \\
\hline Haloperidol & $46 \pm 10$ & 45 & 58 \\
\hline Iloperidone & $0.17 \pm 0.03$ & 0.16 & 0.19 \\
\hline Isoclozapine & $1.8 \pm 0.2$ & 1.8 & 2.1 \\
\hline Isoloxapine & $3.7 \pm 0.5$ & 3.6 & 3.9 \\
\hline Loxapine & $1.8 \pm 0.3$ & 1.8 & 2 \\
\hline Melperone & 150 & 140 & 175 \\
\hline Molindone & 5,800 & 5,800 & 5,800 \\
\hline Olanzapine & $2.3 \pm 0.5$ & $2.3^{c}$ & 3 \\
\hline$\left[{ }^{3} \mathrm{H}\right]$-olanzapine & 1.6 & & \\
\hline Perlapine & 13 & 12 & 20 \\
\hline Raclopride & 3,900 & 3,800 & 4,400 \\
\hline Remoxipride & 5,200 & 5,400 & 6,400 \\
\hline Risperidone & $0.21 \pm 0.05$ & 0.22 & 0.20 \\
\hline Ritanserin & $0.54 \pm 0.1$ & 0.52 & 0.55 \\
\hline Seroquel & 110 & 110 & 135 \\
\hline Sertindole & $0.3 \pm 0.03$ & 0.3 & 0.29 \\
\hline Thioridazine & $1.1 \pm 0.2$ & 1 & 1.3 \\
\hline Trifluperazine & $7.6 \pm 1.5$ & 7.6 & 8.4 \\
\hline
\end{tabular}

\footnotetext{
"Extrapolated radioligand-independent $K$ values, using procedure in Figure 2 and using radioligand partition values that include nonspecific binding to the filter, as shown in Figure 1.

"Extrapolated radioligand-independent $K$ values, using procedure in Figure 2 and using radioligand partition values from which nonspecific binding to the filter has been subtracted.

'Average of $K_{d}$ (of $1.6 \mathrm{nM}$, using $\left[{ }^{3} \mathrm{H}\right]$-olanzapine) and extrapolated radioligand-independent $K$ value.
} 
reliable dissociation constants for these neuroleptics at the various receptors.

Furthermore, as stated in the review, our recent findings with $\mathrm{D}_{4}$-selective $\left[{ }^{3} \mathrm{H}\right]$-ligands indicated that there were no detectable amounts of true dopamine $\mathrm{D}_{4}$ receptors in either human control or schizophrenia striata. This is no justification, however, in discarding the dopamine $\mathrm{D}_{4}$ receptor as a target for drug development, as Drs. Roth and Sibley recommend. It may well emerge that $D_{4}$ blockade by the new $D_{4}$-selective drugs (Kulagowski et al. 1996; Rowley et al. 1996; Boyfield et al. 1996) is not clinically antipsychotic, as mentioned by Dr. Wong (Kramer et al. 1996), but such blockade may have another neuropsychopharmacological role, such as possibly alleviating the Parkinsonism of $\mathrm{D}_{2}$ blockade. It is the purpose of the review to examine this as only one possibility.

Using the data of Roth et al. (1994) for the neuroleptic dissociation constants at the rat cloned $5-\mathrm{HT}_{6}$ receptor, and the data in Table 1 (see review) for the human cloned dopamine $\mathrm{D}_{2}$ receptor, the relation between the catalepsy doses and the ratio of the $\mathrm{D}_{2}: 5-\mathrm{HT}_{6}$ dissociation constants is shown in Figure 8 (top, this article). Clozapine and olanzapine are selective for the $5-\mathrm{HT}_{6}$ receptor, suggesting that this receptor, when blocked, may alleviate $\mathrm{D}_{2}$-associated catalepsy. Although melperone and perlapine are identified in Figure 8, these neuroleptics have high dissociation constants at $D_{2}$, suggesting that they may be readily displaced (see Discussion in the review). Altogether, however, there are too few atypical neuroleptics in Figure 8 (top) to establish clearly whether neuroleptic selectivity for the $5-\mathrm{HT}_{6}$ receptor is or is not predictive of an atypical clinical action by a neuroleptic. The $5-\mathrm{HT}_{6}$ receptor may play an important role, and further research on this point is warranted.

\section{Are Atypical Neuroleptics Selective for the $5-\mathrm{HT}_{7}$ Receptor?}

Using the data of Roth et al. (1994) for the neuroleptic dissociation constants at the rat cloned $5-\mathrm{HT}_{7}$ receptor and the data in Table 1 for the human cloned dopamine $\mathrm{D}_{2}$ receptor, the relation between the catalepsy doses and the ratio of the $\mathrm{D}_{2}: 5-\mathrm{HT}_{7}$ dissociation constants is shown in Figure 8. (bottom). Olanzapine, an important atypical drug, does not fit this relation in Figure 8 (bottom). The $5-\mathrm{HT}_{7}$ receptor is unlikely, therefore, to play an important role in predicting whether a neuroleptic may have an atypical clinical action.

\section{Selective Antagonists for $5-\mathrm{HT}_{2 \mathrm{~A}}$ Receptors and Dopamine $\mathrm{D}_{4}$ Receptors}

Drs. Roth and Sibley state that "With respect to the $D_{4}$ dopamine receptor and the treatment of schizophrenia there has been much sound and fury, but little bona fide
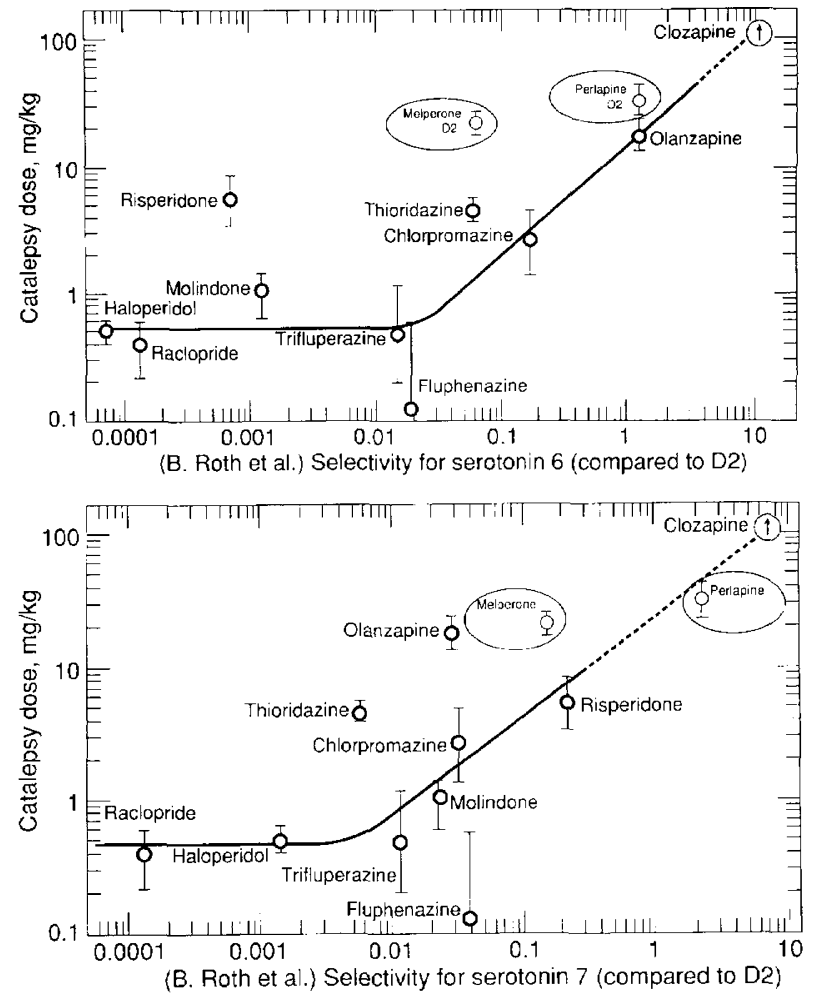

Figure 8. Top, Neuroleptic doses for catalepsy of $50 \%$ of the rats in relation to the ratio of the neuroleptic dissociation constants for the rat cloned serotonin, receptors (from Roth et al. 1994) and the dissociation constants in Table 1 for the human cloned dopamine $\mathrm{D}_{2}$ receptor. Although melperone and perlapine are identified here, these neuroleptics have high dissociation constants at $\mathrm{D}_{2}$, suggesting that they may be readily displaced. Bottom, same as top, except that data are for the rat cloned serotonin $r$ receptor (data from Roth et al. 1994).

evidence." However, evidence is seriously lacking for a clear role for serotonin receptors in the treatment of schizophrenia, despite the long-standing and aggressive marketing to clinical psychiatrists of the concept of serotonin-dopamine-antagonism in treating schizophrenia. For example, a number of positron tomography studies indicate that the occupancy of $5-\mathrm{HT}_{2 \mathrm{~A}}$ receptors is not required for antipsychotic action. As Nyberg et al. (1996) have stated, based on their examination of the occupancy of serotonin receptors by many neuroleptics in human subjects: "Clearly, a 5- $\mathrm{HT}_{2}$ receptor blockade is not a prerequisite for the antipsychotic effects induced by classic neuroleptics."

At present, the dopamine $\mathrm{D}_{2}$ receptor is the only receptor that needs to be blocked to achieve an antipsychotic effect. This also holds for clozapine (Seeman and Kapur submitted).

The data in Figure 7 illustrate that the neuroleptic doses (for catalepsy) weakly correlated with the neuroleptic selectivities for the $5-\mathrm{HT}_{2 \mathrm{~A}}$ receptor and more strongly correlated with the neuroleptic selectivities for 
the dopamine $D_{4}$ receptor. (The term selectivity here is used to indicate the neuroleptic dissociation constant at the 5- $\mathrm{HT}_{2 \mathrm{~A}}$ receptor or at the dopamine $\mathrm{D}_{4}$ receptor, relative to the dissociation constant at the $\mathrm{D}_{2}$ receptor.)

Because the correlation coefficient for the catalepsy$\mathrm{D}_{4}$ receptor relation was significantly high, the blockade of the dopamine $D_{4}$ receptor may contribute to the atypical action of a neuroleptic. It is necessary to emphasize, however, that the blockade of dopamine $\mathrm{D}_{2}$ receptors continues to be a necessary minimum to attain antipsychotic activity (Seeman and Kapur submitted).

Dr. Wong may be correct, therefore, in proposing a future neuroleptic with an appropriate $D_{2}: D_{4}$ affinity that would be clinically effective in inducing low levels of Parkinsonism.

To resolve the question of which of the two receptors (the 5- $\mathrm{HT}_{2 \mathrm{~A}}$ receptor or the dopamine $\mathrm{D}_{4}$ receptor) contributes more effectively to the low level of Parkinsonism will require new neuroleptics with higher selectivities for either the $5-\mathrm{HT}_{2 \mathrm{~A}}$ receptor (such as MDL $100,907)$ or the dopamine $D_{4}$ receptor.

Although ritanserin is selective for $5-\mathrm{HT}_{2 \mathrm{~A}}$ receptors, it has a 10-nM dissociation constant for the $\mathrm{D}_{2}$ receptor (Table 2, this article). Thus, depending on the clinical dose used, one would expect ritanserin to occupy $D_{2}$ receptors and to allay psychotic symptoms. For example, low doses of ritanserin would occupy about one dopamine $\mathrm{D}_{2}$ receptor for every 10 serotonin $_{2 \mathrm{~A}}$ receptors occupied. Hence, the value of $10 \mathrm{nM}$ for ritanserin at the $\mathrm{D}_{2}$ receptor may account for the modest antipsychotic action of ritanserin (Meibach 1989; Duinkerke et al. 1993; Heck et al. 1994; Weisel et al. 1994). Although Weisel et al. found that doses of 10 to $30 \mathrm{mg}$ of ritanserin did not affect the binding of $\left[{ }^{11} \mathrm{C}\right]$-raclopride to the $\mathrm{D}_{2}$ receptors in three patients, ritanserin binds with low affinity (K of $10 \mathrm{nM}$ ) and would be expected to have a low occupancy of the $\mathrm{D}_{2}$ receptors, similar to the situation with clozapine (Conley et al. 1996; Farde et al. 1992; Karbe et al. 1991; Louerens et al. 1993; Nordström et al. 1996). Moreover, it also has been found that ritanserin, in contrast to clozapine, does not alleviate the extrapyramidal effects of haloperidol, but rather elicits a $\mathrm{D}_{2}$-like dystonia in haloperidol-sensitized primates (Casey 1991). Hence, it is likely that doses of ritanserin higher than $30 \mathrm{mg}$ per day would be significantly antipsychotic via $\mathrm{D}_{2}$ blockade.

\section{Dopamine $D_{2}$ Receptor Dimers}

As stated in the review, the elevation of the $D_{4}$-like binding sites in schizophrenia tissues does not reflect true $\mathrm{D}_{4}$ receptors but may actually represent an increase in the amount of dopamine $\mathrm{D}_{2}$ receptor monomers.

The existence of $\mathrm{D}_{2}$ receptor monomers and dimers arose from the observations that the apparent molecular weight of $D_{2}$ was between 92,000 and 150,000 Daltons, as determined by radiation inactivation (Lilly et al.
1983) and photolabeling experiments (Niznik et al 1986; Jarvie et al. 1989; Jarvie and Niznik 1989), in contrast to the size of about 46,000 Daltons for the cloned dopamine $\mathrm{D}_{2}$ receptor.

In addition, the number of $\left[{ }^{3} \mathrm{H}\right]$-nemonapride binding sites for cloned dopamine $\mathrm{D}_{2}$ receptors was always higher than the number of $\left[{ }^{3} \mathrm{H}\right]$-spiperone binding sites (Seeman et al. 1992). This observation had consistently been seen previously by Niznik et al. (1985) for dopamine $D_{2}$ receptors in canine striatum (homogenates and solubilized), porcine anterior pituitary, human caudate, and rat striatum. Terai et al. (1989) also found the binding of $\left[{ }^{3} \mathrm{H}\right]$-nemonapride to exceed that of $\left[{ }^{3} \mathrm{H}\right]$-spiperone in the rat striatum. The density of $\mathrm{D}_{2}$ sites labeled by $\left[{ }^{3} \mathrm{H}\right]$-nemonapride invariably exceeds that labeled by $\left[{ }^{3} \mathrm{H}\right]$-spiperone in every postmortem human brain striatum tested (over 100 brains examined; Seeman et al. 1993a, 1993b).

As noted by Dr. Wong, the same type of finding occurs in clinical positron tomography of dopamine $\mathrm{D}_{2}$ receptors in human subjects. The density of $\mathrm{D}_{2}$ sites labeled by $\left[{ }^{11} \mathrm{C}\right]$-raclopride is invariably $20 \%$ higher ( $\mathrm{L}$. Farde, personal communication) or $80 \%$ higher (Wong et al. 1992, 1993) than the density of $\left[{ }^{11} \mathrm{C}\right]$-methylspiperone sites in the human striatum. For example, the density of $\mathrm{D}_{2}$ sites labeled by $\left[{ }^{11} \mathrm{C}\right]$-spiperone ranges from 15 to $24 \mathrm{pmol} / \mathrm{g}$ (Tune et al. 1993; Wong et al. 1993; Nordström et al. 1995), whereas the density of $D_{2}$ sites labeled by $\left[{ }^{11} \mathrm{C}\right]$-raclopride ranges from 24 to $28 \mathrm{pmol} / \mathrm{g}$ (Farde et al. 1990, 1995; Wong et al. 1995).

Dr. Strange states, however, that Vile et al. (1995) did not find any difference between the number of binding sites detected by $\left[{ }^{3} \mathrm{H}\right]$-nemonapride and $\left[{ }^{3} \mathrm{H}\right]$-spiperone. The actual data published by Vile et al. (1995), however, indicate otherwise, namely that the $B_{\max }$ or density of $\left[{ }^{3} \mathrm{H}\right]$-nemonapride sites exceeded that for $\left[{ }^{3} \mathrm{H}\right]$-spiperone by $16 \%$ to $26 \%$ for cloned $D_{2 \text { (short) }}, 11 \%$ to $17 \%$ for cloned $\mathrm{D}_{2(\text { long) }}$ and $11 \%$ for the rat striatum. Apparently, not a single experiment done by Vile et al. (1995) ever revealed more $\left[{ }^{3} \mathrm{H}\right]$-spiperone sites than $\left[{ }^{3} \mathrm{H}\right]$-nemonapride sites, something that would be expected for at least one experiment if the densities were identical. We do not, therefore, accept Dr. Strange's view that thie radioligand densities were identical.

The balance between $\mathrm{D}_{2}$ monomers and dimers may well depend on experimental conditions, as outlined for muscarinic receptor oligomers by Wreggett and Wells (1995), and this factor may account for identical $\mathrm{D}_{2}$ densities measured by Malmberg et al. (1996).

In addition, we recently tested the radioligand-binding properties of the dopamine $\mathrm{D}_{2}$ receptor monomers and dimers, using two photoaffinity radioligands, $\left[{ }^{125} \mathrm{I}\right]$-azidophenethyl-spiperone and [125I]4-azido-5-iodonemonapride ( $\mathrm{Ng}$ et al., 1996). We found that $\left.{ }^{125} \mathrm{I}\right]$-azidophenethylspiperone labeled the monomer, whereas [ $\left.{ }^{125} \mathrm{I}\right]-4$-azido-5iodonemonapride labeled both the monomers and the 
dimers. These data indicate that the spiperone and benzamide congeners labeled different populations of the $D_{2}$ receptor, resolving the density discrepancies found with these two radioligands in human brain positron tomography (Tune et al. 1993; Wong et al. 1993; Nordström et al. 1995; Farde et al. 1990, 1995; Wong et al. 1995). In other words, because the benzamide attaches to both monomers and dimers, the density of $\left[{ }^{11} \mathrm{Cl}\right.$-raclopride sites in human subjects exceed the density of $D_{2}$ monomer sites labeled by $\left[{ }^{11} \mathrm{C}\right]$-methylspiperone.

It appears, therefore, that the dopamine $\mathrm{D}_{2}$ receptorbinding properties of $\left[{ }^{11} \mathrm{C}\right]$ raclopride and $\left[{ }^{11} \mathrm{C}\right]$-methylspiperone may differ, in agreement with the comments of Dr. Wong. This has considerable implications for the measurement of $D_{2}$ receptors in schizophrenia, wherein $\left[{ }^{11} \mathrm{C}\right]$-raclopride reveals no elevation of $\mathrm{D}_{2}$ receptors (Farde et al. 1990), but $\left[{ }^{11} \mathrm{C}\right]$-methylspiperone does (Wong et al. 1986; Gjedde et al. 1995; Nordström et al. 1995), although these latter authors state that the 33\% elevation of $D_{2}$ they found was not statistically significant. Clearly, therefore, we have much yet to learn about how dopamine $\mathrm{D}_{2}$ receptors behave in health and disease.

P. Seeman, M.D., Ph.D.

R. Corbett, Ph.D.

H.H.M. Van Tol, Ph.D.

\section{REFERENCES}

Boyfield I, Brown TH, Coldwell MC, Cooper, Hadley MS, Hagan JJ, Healy MA, Johns A, King RJ, Middlemiss DN, Nash DJ, Riley GJ, Scott EE, Smith SA, Stemp G (1996): Design and synthesis of 2-naphthoate esters as selective dopamine $\mathrm{D}_{4}$ antagonists. J Med Chem 39:1946-1948

Burt DR, Creese I, Snyder SH (1976): Properties of [ $\left.{ }^{3} \mathrm{H}\right]$ haloperidol and $\left[{ }^{3} \mathrm{H}\right]$ dopamine binding associated with dopamine receptors in calf brain membranes. Mol Pharmacol 12:800-812

Casey DE (1991): The effect of a serotonin $S_{2}$ antagonist, ritanserine, and an anticholinergic benztropine on haloperidol-induced dystonia in nonhuman primates. Meeting of the American College of Neuropsychopharmacology (Abstr) 30:127

Conley R, Zhao M, Wong D, Tamminga C (1996): ${ }^{11}$ C NMSP receptor occupancy by clozapine and haloperidol in schizophrenic subjects. Biol Psychiatr 39:513

Duinkerke SJ, Botter PA, Jansen AAI, Van Dongen PAM, Van Haaften AJ, Boom AJ, Van Laarhoven JHM, Busard HLSM (1993): Ritanserin, a selective $5-\mathrm{HT}_{2 / 1 \mathrm{C}}$ antagonist, and negative symptoms in schizophrenia. Brit J Psychiatr 163:451-455

Farde L, Wiesel F-A, Stone-Elander S, Halldin C, Nordström A-L, Hall H, Sedvall G (1990): $D_{2}$ dopamine receptors in neuroleptic-naive schizophrenic patients. Arch Gen Psychiatr 47:213-219

Farde L, Nordström A-L, Wiesel F-A, Paul S, Halldin C, Sedvall G (1992): Positron emission tomographic analysis of central $D_{1}$ and $D_{2}$ dopamine receptor occupancy in patients treated with classical neuroleptics and clozapine. Arch Gen Psychiatr 49:538-544

Farde L, Hall H, Paul S, Halldin C (1995): Variability in $D_{2}$ dopamine receptor density and affinity: A PET study with $\left[{ }^{11} \mathrm{C}\right]$ raclopride in man. Synapse 20:200-208

Gjedde A, Reith J, Wong DF (1995): Dopamine receptors in schizophrenia. Lancet 346:1302-1303

Heck AH, Post P, Daubenton F, Vahlne J-O, Olbrich R (1994): Ritanserin, a selective serotonin antagonist as adds-on treatment in schizophrenia. Neuropsychopharmacology 10(supp 3):207S

Jarvie KR, Niznik HB, Seeman $P(1988)$ : Dopamine $D_{2}$ receptor binding subunits of $\mathrm{Mr} \sim 140,000$ and 94,000 in brain: Deglycosylation yields a common unit of $\mathrm{Mr} \sim$ 44,000. Mol Pharmacol 34:91-97

Jarvie KR, Niznik HB (1989): Deglycosylation and proteolysis of photolabeled $D_{2}$ dopamine receptors of the porcine anterior pituitary. J Biochem 106:17-22

Karbe H, Wienhard K, Hamacher K, Huber M, Herholz K, Coenen HH, Stöcklin G, Lövenich A, Heiss WD (1991): Positron emission tomography with $\left({ }^{18} \mathrm{~F}\right)$ methylspiperone demonstrates $\mathrm{D}_{2}$ dopamine receptor binding differences of clozapine and haloperidol. J Neural Transm 86:163-173

Kramer M, Zimbroff D, Last B, Getson A (1996): The effects of a selective $\mathrm{D}_{4}$ antagonist (L-745,870) in acutely psychotic schizophrenic patients. NCDEU Meeting, Abstr. 106, May 28

Kulagowski JJ, Broughton HB, Curtis NR, Mawer IM, Ridgill MP, Baker R, Emms F, Freedman SB, Marwood R, Patel S, Patel S, Ragan CI, Leeson PD (1996): 3-[[4-(4-chlorophenyl)piperazin-1-yl]methyl]-1H-pyrrolo[2,3-b]pyridine: An antagonist with high affinity and selectivity for the human dopamine $\mathrm{D}_{4}$ receptor. J Med Chem 39:19411942

Lilly L, Fraser CM, Jung C, Seeman P, Venter IC (1983): Molecular size of the canine and human brian $D_{2}$ dopamine receptor as determined by radiation inactivation. Mol Pharmacol 24:10-14

Louwerens JW, Buddingh JA, Zijlstra S, Pruim J, Korf J, Paans AMJ, Vaalburg W, Sloof CJ (1993): Dopamine $\left(\mathrm{D}_{2}\right)$-receptor occupancy in clozapine-treated patients as measured by positron emission tomography using ${ }^{18}$ FESP, In Brunello N, Mendlewicz J, Racagni G, (eds), New Generation of Antipsychotic Drugs: Novel Mechanisms of Action. Basel: Karger, 4:130-135

Malmberg $\AA$ A, Jerning E, Mohell N (1996): Critical reevaluation of radiolabeled spiperone and benzamide binding to dopamine $\mathrm{D}_{2}$ receptors; evidence for identical binding sites. Eur J Pharmacol 30:123-128

Meibach RC (1989): The role of $5-\mathrm{HT}_{2}$ receptor antagonism in the treatment of schizophrenia. Meeting of the American College of Neuropsychopharmacol (Abstr) 28:12

Newman-Tancredi A, Chaput C, Verriele L, Millan MJ (1996): Clozapine is a partial agonist at cloned, human serotonin 5- $\mathrm{HT}_{1 \mathrm{~A}}$ receptors. Neuropharmacology 35: 119-121

Ng GYK, O’Dowd BF, Lee SP, Chung HT, Brann MR, Seeman P, George SR (1996): Dopamine D2 receptor dimers 
and receptor-blocking peptides. Biochem Biophys Res Commun 227:200-204

Niznik HB, Grigoriadis DE, Pri-Bar I, Buchman O, Seeman P (1985): Depamine $D_{2}$ receptors selectively labeled by a benzamide neuroleptic: [ $\left.{ }^{3} \mathrm{H}\right]-Y M-09151-2$. Nuanyn Schmiedbergs Arch Pharmacol 329:333-343

Niznik HB, Grigoriadis DE, Seeman P (1986): Photoaffinity labelling of dopamine $\mathrm{D}_{2}$ receptors by $\left[{ }^{3} \mathrm{H}\right.$ ]azidomethylspiperone. FEBS Lett 209:71-76

Nordström A-L, Farde L, Eriksson L, Halldin C (1995): No elevated $D_{2}$ dopamine receptors in neuroleptic-naive schizophrenic patients revealed by positron emission tomography and $\left[{ }^{11} \mathrm{C}\right] N$-methylspiperone. Psychiatr Res: Neuroimaging 61:67-83

Nordström A-L, Farde L, Nyberg S, Karlsson P, Halldin C, Sedvall $G$ (1996): $D_{1}, D_{2}$, and $5-H_{2}$ receptor occupancy in relation to clozapine serum concentration: A PET study of schizophrenic patients. Am J Psychiatr 152: 1444-1449

Nyberg S, Nakashima Y, Nordström A-L, Halldin C, Farde L (1996): Positron emission tomography of in-vivo binding characteristics of atypical antipsychotic drugs. Review of $\mathrm{D}_{2}$ and 5- $\mathrm{HT}_{2}$ receptor occupancy studies and clinical response. Brit J Psychiatr 168(suppl29):40-44

Roth BL, Craigo SC, Choudhary MS, Uluer A, Monsma Jr FJ, Shen Y, Meltzer HY, Sibley DR (1994): Binding of typical and atypical antipsychotic agents to 5-hydroxytryptamine- 6 and 5-hydroxytryptamine-7 receptors. J Pharmacol Exp Ther 268:1403-1410

Rowley M, Broughton HB, Collins I, Baker R, Emms F, Marwood R, Patel S, Patel S, Ragan CI, Freedman SB, Leeson PD (1996): 5-(4-Chlorophenyl)-4-methyl-3-(1-(2-phenylethyl)piperidin-4-yl)isoxazole: A potent, selective antagonist at human cloned dopamine $\mathrm{D}_{4}$ receptors. J Med Chem 39:1943-1945

Seeman P (1972): The membrane actions of anesthetics and tranquilizers. Pharmacol Rev 24:583-655

Seeman P (1980): Brain dopamine receptors. Pharmacol Rev 32:229-313

Seeman P, Van Tol HHM (1995): Deriving the therapeutic concentrations for clozapine and haloperidol: The apparent dissociation constant of a neuroleptic at the dopamine $\mathrm{D}_{2}$ or $\mathrm{D}_{4}$ receptor varies with the affinity of the competing radioligand. Eur J Pharmacol - Mol Pharmacol 291:59-66

Seeman P, Staiman A, Chau-Wong M (1974): The nerve impulse-blocking actions of tranquilizers, and the bind- ing of neuroleptics to synaptosome membranes. J Pharmacol Exp Ther 190:123-130

Seeman P, Guan H-C, Van Tol HHM, Niznik HB (1993a): Low density of dopamine $\mathrm{D}_{4}$ receptors in Parkinson's, schizophrenia and control brain striata. Synapse 14:247253

Seeman P, Guan H-C, Van Tol HHM (1993b): Dopamine $D_{4}$ receptors are elevated in schizophrenia. Nature 365:441445

Terai M, Hidaka K, Nakamura Y (1989): Comparison of $\left[{ }^{3} \mathrm{H}\right] \mathrm{YM}-09151-2$ with $\left[{ }^{3} \mathrm{H}\right]$ spiperone and $\left[{ }^{3} \mathrm{H}\right]$ raclopride for dopamine $\mathrm{D}_{2}$ receptor binding to rat striatum. Eur J Pharmacol 173:177-182

Tune LE, Wong DF, Pearlson G, Strauss M, Young T, Shaya EK, Dannals RF, Wilson AA, Ravert HT, Sapp J, Cooper T, Chase GA, Wagner Jr HN (1993): Dopamine $D_{2}$ receptor density estimates in schizophrenia: A positron tomography study with ${ }^{11} \mathrm{C}-\mathrm{N}$-methylspiperone. Psychiatr Res 49:219-237

Vile JM, D'Souza UM, Strange PG (1995): [ $\left.{ }^{3} \mathrm{H}\right]$ Nemonapride and $\left[{ }^{3} \mathrm{H}\right]$ spiperone label equivalent numbers of $D_{2}$ and $\mathrm{D}_{3}$ dopamine receptors in a range of tissues and under different conditions. J Neurochem 64:940-943

Weisel F-A, Nordström A-L, Farde L, Eriksson B (1994): An open clinical and biochemical study of ritanserin in acute patients with schizophrenia. Psychopharmacology 114:31-38

Wong DF, Wagner Jr HN, Tune LE, Dannals RF, Pearlson GD, Links JM, Tamminga CA, Broussolle EP, Ravert HT, Wilson AA, Toung JKT, Malat J, Williams JA, O'Tauma LA, Snyder SH, Kuhar MH, Gjedde A (1986): Positron emission tomography reveals elevated $D_{2}$ dopamine receptors in drug-naive schizophrenics. Science 234:1558-1563

Wong DF, Shaya E, Pearlson G, Yung B, Dannals RF, Wilson AA, Ravert HT, Wagner Jr HN, Gjedde A (1992): The comparison of dopamine receptor density measured by C-11 raclopride and NMSP in the same living human brain. J Nucl Med 33:847 Abstr

Wong DF, Tune L, Shaya E, Pearlson G, Yung B, Dannals RF, Wilson AA, Ravert HT, Wagner Jr HN, Gjedde A (1993): Dopamine receptor density measured by C-11 raclopride and NMSP in the same schizophrenic patients and normal subjects. Schizophrenia Res 8:212

Wreggett KA, Wells JW (1995): Cooperativity manifest in the binding properties of purified cardiac muscarinic receptors. J Biol Chem 270:22488-22499 